\title{
ANALYSIS OF VEGETATION IN SPECIAL PURPOSE FOREST OF TUMBANG NUSA, JABIREN RAYA SUBDISTRICT, CENTRAL KALIMANTAN
}

\author{
Sosilawaty, Yanarita, Tudi Andrean \\ Department of Forestry, Faculty of Agricultural \\ University of Palangka Raya, Palangka Raya, Central Kalimantan, Indonesia \\ Email : susisiboth@gmail.com
}

\begin{abstract}
Forests are natural resources that provide double benefits, direct and indirect benefits. The direct benefit of forest is as a source of various types of goods, such as woods, saps, barks, leaves, roots, fruits, and flowers that can be used directly by humans or become raw materials for various industries. The specialpurpose forest of Tumbang Nusa is a secondary peat swamp forest. Peat swamp forest is a forest formation quite widespread in Indonesia. The term arises because swamp forest and peat forest are basically always adjacent and often do not have clear boundaries that are so-called peat swamp forests. The purpose of this study was to find out the structure and species composition (species dominance, species diversity, species richness and species evenness) of secondary peat swamp forest vegetation in specialpurpose forest of Tumbang Nusa, Jabiren Raya Subdistrict, Central Kalimantan Province. The results of the study showed that the vegetation structure by diameter classes was dominated by the vegetation with small diameter $(0-9 \mathrm{~cm})$ and by height classes was dominated by the vegetation with low height-class $(0-5 \mathrm{~m})$. The diversity of vegetation in the study plots showed that there were 42 species of vegetation consisting of 24 families, and the most common species found were the family of Lauraceae (5 species), Dipterocarpaceae (4 species), Myristicaceae, Myrtaceae and Guttiferae (3 species), Podocarpaceae, Apocynaceae, Ebenaceae, Moraceae and Annonaceae (2 species), and a few other family (one species of each). The species diversity at seedling and sapling stages was moderate $\left(\mathrm{H}^{\prime} \geq 2\right.$ and $<3$ ) while the diversity at pole and tree stages was low $\left(H^{\prime}<2\right)$. The values of species richness index at seedling, sapling and pole stages were moderate $(R=3.5-5.0)$ while at the tree stage was relatively low $(R>3.5)$. The species evenness index at seedling and sapling stages was high $(E>0.6)$ while at the pole and tree stages moderate $(E=0.3$ to 0.6$)$.
\end{abstract}

Keywords: biodiversity, forest, peat swamp, secondary forest

\section{INTRODUCTION}

Peat swamp forests have a specific ecosystem, and can be well preserved because of the linkage between the constituent components in it as a unified whole. The peat swamp forests also have a high biological diversity, and many of the species are endemic. The forests have undergone many changes and damages, thus decreasing the functions of the forests. Due to the decreased functions, the resources in the forests including the vegetation diversity will experience changes.

The objective of this study was to study the structure and composition of secondary peat swamp forest vegetation in the specialpurpose forest of Tumbang Nusa, Jabiren Raya Subdistrict, Central Kalimantan.

The study is expected to provide information on the species diversity of secondary forest in the study site so that the results of the study can be used as the reference in the management of peat swamp forest in the special-purpose forest of Tumbang Nusa.

\section{MATERIALS AND METHODS}

The study was conducted in the specialpurpose forest of Tumbang Nusa, Pulang Pisau Regency, Central Kalimantan Province for \pm 3 months (January to March).

The object observed in this study was the vegetation at seedling, sapling, pole and tree stages found in the special-purpose forest of Tumbang Nusa.

\section{Important Value Index (IVI)}

Important Value Index (IVI) can be calculated using the formula by Soerianegara and Indrawan (1978), as follows:

Important Value Index (IVI) for pole and tree stages:

IVI = Relatif Density + Relatif Frequency + Relatif Dominance

Important Value Index (IVI) for seedling and sapling stages: 
IVI = Relatif Density + Relatif Frequency

Diversity Index (H')

Note:

$$
\mathrm{H} \square=-\sum\left[\left(\frac{n i}{N}\right) \ln \left(\frac{n i}{N}\right)\right]
$$

$\mathrm{H} \square \quad=$ Species Diversity Index

$\mathrm{Ni} \quad=$ Number of Individuals of a certain species

$\mathrm{N} \quad=$ Number of Individuals of all species

In $\quad=$ Natural Logarithm

\section{Species Richness Index (R)}

Note :

$$
\mathrm{R}=\frac{S-1}{\operatorname{In}(n)}
$$

$\mathrm{R}=$ Richness Index

$\mathrm{N} \quad=$ Number of Total Individuals

In $\quad=$ Natural Logarithm

$\mathrm{S} \quad=$ Number of Species
Species Evenness Index (E)

Note :

$$
\mathrm{E}=\frac{H^{\prime}}{\operatorname{In}(s)}
$$

$\mathrm{E} \quad=$ Evenness Index

$\mathrm{H} \square \quad=$ Evenness Index of Species

$\mathrm{S} \quad=$ Number of Species

In = Natural Logarithm

\section{RESULTS AND DISCUSSION}

Structure of vegetation based on diameter classes in Table 1 shows that the distribution of diameter classes of vegetation in the study plots was dominated by plant species with small diameter $(0-9 \mathrm{~cm})$, and its density decreased in the larger diameter classes (> 39 $\mathrm{cm}$ ). The small-diameter vegetation had the higher density than the large-diameter vegetation $(>39 \mathrm{~cm})$.

Table 1 Structure of Vegetation Based on Distribution of Diameter Classes in Study Plots

\begin{tabular}{ccc}
\hline No & Diameter Class $(\mathrm{cm})$ & Density $(\mathrm{N} / \mathrm{ha})$ \\
\hline 1 & $0-9$ & 33,678 \\
2 & $10-19$ & 19,114 \\
3 & $20-29$ & 9,050 \\
4 & $30-39$ & 232 \\
5 & $>39$ & 287 \\
\hline
\end{tabular}

Structure of vegetation based on height classes in Table 2 shows that the density based on the distribution of height classes in the study

Table 2 Structure of Vegetation Based on Height Classes in Study Plots

\begin{tabular}{ccc}
\hline No & Height Classes $(\mathrm{m})$ & Density $(\mathrm{N} / \mathrm{ha})$ \\
\hline 1 & $0-5$ & 32,020 \\
2 & $6-10$ & 19,490 \\
3 & $11-15$ & 9,719 \\
4 & $16-20$ & 1,132 \\
\hline
\end{tabular}

\section{Dominance at Seedling Stage}

The number of vegetation at the seedling stage was 29 species from 19 families. Of the 29 species, there were 3 (three) dominant species classified by IVI, namely Pintik Pampaning (17.62\%).

\section{Dominance at Sapling State}

The number of vegetation at sapling stage was 28 species consisting of 21 families. Of the 28 species there were 3 (three) dominant species classified by IVI, namely Pintik $(28.59 \%)$, Kopi-kopi $(18.58 \%)$, and Tumih (16.31\%). $(52.38 \%)$, Madang lengkuas $(20.78 \%)$, and plots was dominated by vegetation with height classes of 0-9 m.

\section{Dominance at Pole Stage}

The number of vegetation at pole stage was 27 species from 21 families. Of the 27 species, there were three (3) dominant species classified by IVI, namely Tumih (120.88\%), Gerunggang (51.99\%), and Kambasira (14.70\%).

\section{Dominance at Pole Stage}

The number of vegetation at tree stage was 17 species from 13 families. There were 3 dominant species at this stage classified by IVI, namely Gerunggang (134.92\%), Tumih (62.78\%), Martibu (24.57\%). 


\section{Diversity Index $(\mathbf{H} \square)$}

The diversity of species found at seedling and sapling stages was moderate with the species diversity index values of $\geq 2$ and $<3$.
Meanwhile, the species diversity index at pole and tree stages was low with the value of $<2$.

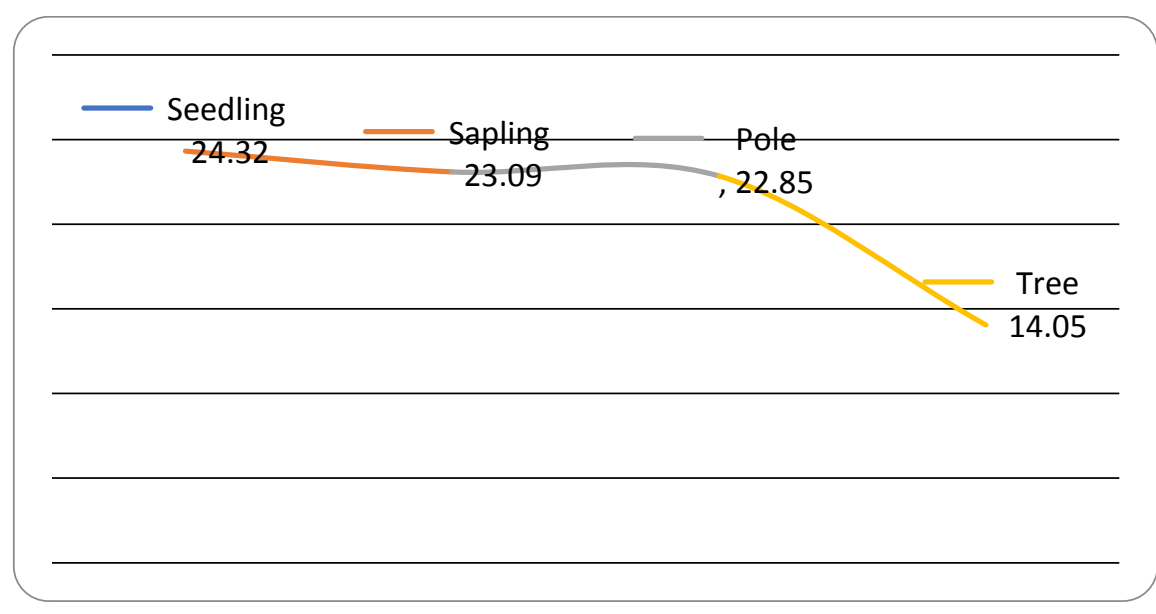

Figure 1 Species Richness Index (R)

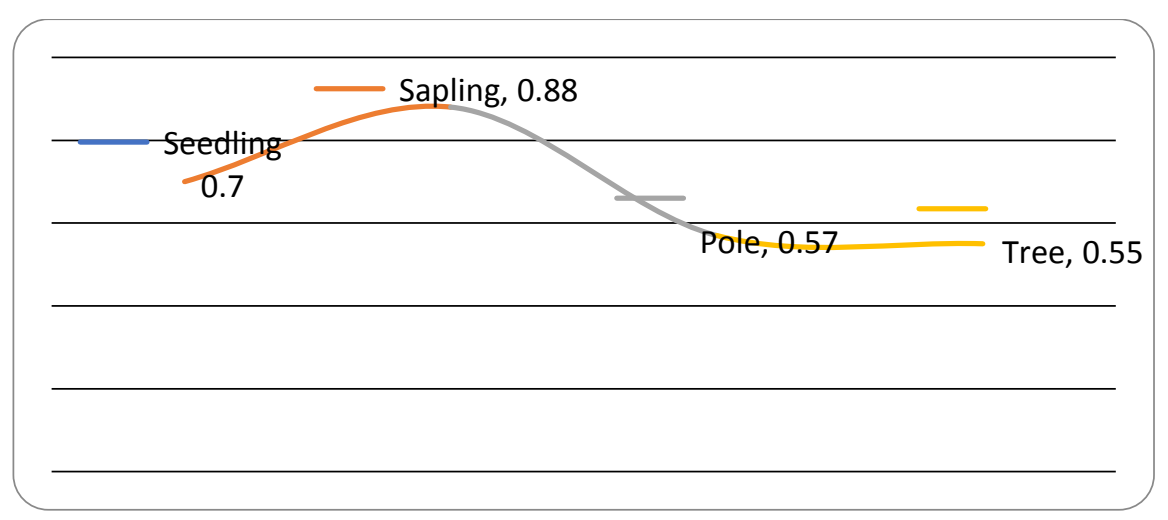

Figure 2 Species Evenness Index (E)

The evenness index values in the study plots for the growth rate of seedlings $(0.70)$ and saplings $(0.88)$ were high; the evenness index was more than $0.6(\mathrm{E}>0.6)$. The evenness index values for the growth rate of poles $(0.57)$ and trees $(0.55)$ was classified moderate, where the evenness index ranged from 0.3 to $0.6(E=0.3$ to 0.6$)$.

\section{CONCLUSIONS}

The structure of vegetation in the study plots in the special-purpose forest of Tumbang Nusa by diameter classes was dominated by small diameter $(0-9 \mathrm{~cm})$ and by height classes was dominated by low height class (0-5 m).

The diversity of vegetation in the study plots in the special-purpose forest of Tumbang Nusa was 42 species dominated by Shorea sp. and 24 families dominated by Lauraceae and Dipterocarpaceae.
The dominant species in the study plots at seedling and sapling stages was Pintik (Leea sp.), at pole stage Tumih (Combretocarpus ratundatus), and at tree stage Gerunggang (Cratoxylum arborescens).

The species diversity in the study plots at seedling and sapling stages was moderate $\left(\mathrm{H}^{\prime} \geq 2\right.$ and $\left.<3\right)$, but at pole and tree stages was low $\left(H^{\prime}<2\right)$. The species richness index in the study plots ranged from 24.32 to 14.05 . The species evenness index in the study plots at seedling and sapling stages was high $(E>$ $0.6)$ and at pole and tree stages moderate ( $E$ $=0.3$ to 0.6 ).

Given the types of vegetation in the special-purpose forest of Tumbang Nusa had low value; the conservation in this study location should be carried out, with the prevention of fires and the enrichment of vegetation types endemic to the forest. 


\section{REFERENCES}

Brown, S. \& Lugo, A. E. (1990). Tropical Secondary Forests. Journal of Tropical Ecology $6: 1$ - 32.

Haryanto (1995). Conservation of Natural Diversity in Tropical Forests. Department of Forest Resource Conservation. Forestry Faculty. Bogor Agricultural University. Bogor.

Haryanto (1995). Montoring Techniques of Plant Diversities. The Department of Forest Resource Conservation. Forestry Faculty. Bogor Agricultural University. Bogor.

Hidayat, N. (2001). Diversity of Stand Dimension Characteristics in Peat Swamp Forests Managed by Indonesian Selective Logging System. A Case Study in Forests of PT. Inhutani II, West Kalimantan. Thesis. Graduate School, Bogor Agricultural University. Bogor.

Ibie, B.F. (1997). Estimation of Stand dimension in Peat Swamp Forests Based on Stand Structure in Arboretum Nyaru Menteng, Palangka Raya. Thesis. Master Program, Bogor Agricultural University, Bogor.

Indriyanto (2006). Forest Ecology. Bumi Aksara. Jakarta.

Kershaw K.A. (1973). Quantitative and Dynamic Plant Ecology. Ed 2nd. Butter and Tanner. London.

Ministry of Environment (2009). Fourth National Report the Convention on Biological Biodiversity. Biodiversity Conservation Unit, Ministry of Environment. Jakarta.

Soerianegara, I. \& Indrawan, A. (1978). Indonesian Forest Ecology. Forestry Faculty, Bogor Agricultural University. Bogor. 